\section{George W. Housner (1910-2008) ${ }^{1}$}

Online material: Publications of George W. Housner

George W. Housner, Carl F Braun Professor of Engineering, emeritus, died after a short illness on 10 November 2008, just a few weeks before his 98th birthday. He was in the retirement home in Pasadena where he had lived for several years. For all of us who knew George, this marked the end of an era. Few people have guided and nurtured a field the way George led earthquake engineering over a period of several decades. He had a profound effect on many people and will long be remembered. His impact was so pervasive that he earned the title "Father of Earthquake Engineering." This article records some of my thoughts about this remarkable man.

First, let me share with readers some facts about his life. He was born 9 December 1910, in Saginaw, Michigan. He had an older brother who died very young, and a sister, a childhood victim of polio, who died as a young adult. He went to public schools in Michigan and enrolled at the University of Michigan, where he obtained a B.S. in civil engineering in 1933. He then moved to California and received his M.S. in civil engineering from the California Institute of Technology (Caltech). After graduation he worked as a prac-

ticing engineer in Los Angeles for six years. He returned to Caltech in 1939 and earned a Ph.D. in civil engineering in 1941. His thesis adviser was R. R. Martel, himself a pioneer in earthquake engineering. George served as a civilian in the Army Air Force during World War II, doing operations analysis in Africa and Italy and finishing his service as Chief of the Operations Analysis Section of the $15^{\text {th }}$ Air Force. He returned to Caltech as an Aassistant Pprofessor after the war in 1945 . He rose through the academic ranks to become a full Pprofessor in 1953 and was awarded the C F Braun Chair of Engineering in 1974. (The correct lack of periods after "C" and " $F$ " is another story.) In 1981, universities still had manda-

1 This article also appears in Earthquake Spectra and Earthquake Engineering and Structural Dynamics. tory retirement, and following his 70th birthday, he became Professor Eemeritus. In this status, he stayed as active as before and continued a high level of professional activities for almost two more decades.

I first met George when I came to Caltech as a graduate student in 1959 . He had an office on the south side of the hallway on the second floor of Thomas Laboratories, one of the engineering buildings at Caltech. He had been a full professor for some time then and had an established reputation as an intellectual leader in applied mechanics and in the new field of earthquake engineering. Of course, I didn't know that at the time, but I came to learn it over the next several months. My first impression was of a big man; it even crossed my mind that he might have been a college football player. Those who know George's lifelong avoidance of strenuous exercise will be amused by my mistake, one that shows clearly the errors that can come from first impressions.

During my first year at Caltech, I slowly became aware of George's depth of understanding in applied mechanics and his skill as a teacher. His low-key style was not what some of the students liked, but most of us were really impressed by his knowledge and deep intuition. He seemed to know just what each term and parameter of an equation meant physically and how it influenced the solution. This level of understanding, which I learned over later years to be virtually unique, helped him solve many problems in mechanics; in particular, he could develop simple solutions that captured the essence of complex phenomena. Notable among these were the problem of flow-induced vibrations in pipelines, the sloshing of fluids in large storage tanks, the behavior of inverted pendulum structures, and the hydrodynamic pressure on dams during earthquakes.

George was my thesis adviser for my doctoral studies. His style as a research mentor is hard to describe. He would ask you what your general interests were and suggest a couple of topics you might look at, or he would give you a paper in an area that he found interesting. He would then ask you to come see him in a couple of weeks. At that meeting he would ask questions about what you had learned-very penetrating questions-and 
make comments. He did not tell you what to do, but continued to make suggestions about things to think about. This process, which I later came to think of as necessary floundering, enabled the students to mature enough to choose an appropriate thesis subject and, with his guidance, pose a manageable program that could lead to a degree. George also helped introduce students to research by giving them a problem to work. Typically, it would be a small problem that could be grasped readily-bigger than a homework problem, but smaller than a thesis topic. Sometimes these starter problems led to small papers, or even to a thesis topic, but their primary purpose was not to generate publications but to give the students experience and confidence in doing research. Overall, this two-part process led to a successful thesis, but more important, it helped the student realize the critical role of the selection of the problem.

His Caltech colleague Don Hudson was George's most frequent co-author, but George and I also wrote many papers together over the years after I joined the Caltech faculty. We also worked on several consulting jobs together. Some of our joint papers arose from research analyses, but a larger number were reports and studies of the effects of damaging earthquakes, and a few were expositions on earthquake design criteria. It was a real learning experience to write a paper with George, as others can testify. After several discussions about the scope of the paper, I often had a try at the first draft, which I then passed on to George. Invariably, he would make additions and changes that added materially to the value of the presentation. My seldom-achieved goal, of course, was to write a draft that required only minor changes to make it to final form.

As a faculty member and colleague, I had the good fortune to work with George on many projects, including post-earthquake studies of several major earthquakes, national research plans for earthquake engineering, and reports of U. S. delegations visiting other countries. Although different in detail, these studies and projects were all team efforts with George at the head. He was a natural leader in this environment. Not only was he skilled at the mechanics of running a project and getting people to work together, but his broad knowledge, evident wisdom, and gentle style made everyone want to work with him. You knew when he was the chair that the effort would be a high-quality success. He obviously had exceptional analytic abilities, but in this context it was more important that he was very smart in a broader sense: he never said anything really off the mark and he nearly always said something wise, the kind of remark you wish you had said. This talent, plus his natural gravitas and bearing, allowed him to successfully discharge the role of a distinguished leader when the teams met with foreign governments or reported to political sponsors. There was no need for him to establish his credentials in such arenas. The first impression he gave was the correct one: that he was a respected leader, someone to be taken seriously.

These same abilities made him a leader in professional societies. He was the first vice president and second president of the Earthquake Engineering Research Institute (EERI) in 1950-1951, following Lydik Jacobsen's one-year term in 1949. He then returned to the presidency for 11 years (1954-1965), whereupon one of his first efforts was to help organize the First World Conference on Earthquake Engineering in 1956 at the University of California, Berkeley. During his long tenure as president, he guided the early development of the institute and laid the groundwork for the later transformation of EERI from a small, invitation-only organization with a focus on the structural aspects of earthquake engineering to the large, broad, open, and multidisciplinary association that it is now. He also was instrumental in the formation of the International Association for Earthquake Engineering (IAEE) and served as its president from 1969 to 1973. This organization now sponsors the World Conferences on Earthquake Engineering and encourages the development of earthquake engineering societies in seismic parts of the world. Additionally, during George's term of office, Earthquake Engineering and Structural Dynamics was formed as the journal of the IAEE, with Ray Clough as the founding editor. George's influence on these organizations continued long after his presidencies were past. He was involved in IAEE activities for many more years as an elder statesman and was one of the key players in the establishment of EERI's successful monograph series.

Working with George over the years on many projects and team efforts, with all the attendant meetings, I learned from him the value of having two people who could work closely together involved in key discussions. It took me a while to understand why he asked me to join him in some of the meetings, as it seemed to me that he could obviously handle things himself. Finally, I deduced from what went on, and confirmed it with George, that having two people present allowed one to think while the other talked. So, I would pitch in now and then with a comment on something I had picked up in the reading or heard in the conversation, thereby giving George a chance to think things over and come back with a refreshed point of view.

One of the things George did that all of his colleagues valued was to send them articles or publications that he thought would be of special interest. Sometimes they were serious, sometimes funny, but they were always something you were glad he sent. Often an item would have a routing guide penned in the margin identifying the people he thought might want to see it. Typically, the last initials on the list were GH. In this way, the article eventually made its way back to him for placement on one of his stacks. It also helped those higher on the list move the item along, as his initials at the bottom carried the implication that George was looking forward to the document's return. Although I thought at first that he only did this for his colleagues at Caltech, I gradually learned that the practice was much more extensive. Once he knew them and their interests, George sent material to colleagues all over the world. It was a valued correspondence that he continued with people for many years.

Another aspect of his leadership was George's special effort to help young people, not only his former students, but others as well. In this sense, he really was the father of earthquake engineering, as well as its conscience. One of the things he did often was to open doors for his younger colleagues to get involved in important activities. In my case, he brought me into the large National Academy of Sciences study of the 1964 
Alaska earthquake shortly after I graduated, first as his assistant and later as a member of the Engineering Panel. In similar ways he also helped many other younger colleagues. Much of this help was informal, but he also spent considerable amounts of his time as a senior professor nominating younger colleagues for prizes and awards and for membership in the National Academy of Engineering. Many of those whom he aided early in their careers have told me over the years of the gratitude they felt for what he had done for them.

George was an excellent writer. I cannot but believe that this was due in large part to his wide and extensive reading, both in the sciences and in the arts. For the documents that came from the many projects he headed, he typically drafted the introduction, conclusions, and parts of the body himself, and edited the rest carefully. Watching this process, I learned a little trick from him. Often, when a colleague's contribution required extensive editing, he would have the manuscript retyped and then send the colleague the clean revision along with a little note saying that he believed that this was what the author intended to say. Since the edited version was clear and concise, and the author was not confronted with the unwelcome sight of his version covered with a sea of changes,; the revisions were always accepted. Another reason for the retyping may have been that George knew that his handwriting was very hard to read and might cause errors if an inexperienced person tried to incorporate his changes into the text. Our department secretary, Alice Gear, and I were the most skilled at deciphering George's penmanship, and we often consulted each other as manuscripts and letters took their final form. Occasionally we were stumped, of course, and had to resort to asking George what he had written.

George's office, to put it politely, was pretty crowded. The bookshelves were jammed with books, reports, and occasional souvenirs, and the floor was filled with more of the same, plus rolls of blueprints and stacks of older correspondence. His desk was covered with smaller piles of papers and more recent correspondence, mostly dealing with current projects. Whatever he was working on at the moment was on top, near his chair, but it rested on top of other papers, rather than having a place to itself on the wooden surface of the desk. Memorabilia, extra copies of conference proceedings, old building plans, slides, and photographs were all kept in a long narrow closet at the rear, a space behind the elevator. The setup suggested chaos and confusion, but George's prodigious memory allowed him to recover material with remarkable reliability. He would think a few seconds and then reach into some pile, stack, or shelf and recover the desired document. As the years went by and many of the piles and stacks seemed to remain unchanged, I asked him why he didn't make his office more livable by throwing some of the stuff away. He replied: "It is important to throw things away, but not too soon."

George received many awards for his accomplishments. These were well deserved, and not because of his longevity, as he once joked. He was elected to the National Academy of Engineering in the first round and was also a member of the National Academy of Sciences. He received numerous presti- gious awards from technical societies and institutions in several nations and was the first recipient of the George W. Housner Medal established in his name by the Earthquake Engineering Research Institute. He received honorary doctorates from the University of Michigan and from the University of Southern California. Perhaps his most prestigious award was the National Medal of Science, given to him by President Ronald Reagan in 1988.

Because George, a lifelong bachelor, lived modestly and invested well over the years, he accumulated substantial assets by professorial standards. He donated all his wealth to charitable purposes. Most of the funds went to Caltech, where his estate has endowed a named professorship and where during his lifetime he endowed funds to support earthquake engineering research and scholarly activities of the undergraduates. He also supported the Caltech Y, the Pasadena Symphony, and other musical and artistic activities.

George was not a gregarious man, but he was a keen observer of human nature and enjoyed the foibles of his fellow man. He was a good storyteller when he chose to be. One of his favorite anecdotes concerned a banquet of a professional society that he had attended. It seems that a well-known geologist, not sitting at the head table, gave the waiters a liberal tip to serve the head table dead last. George described with amusement the antics of the famous folk at the head table as they tried in vain to catch the waiters' attention and get their meal. Another story he liked to tell was about a seismological colleague. At a technical meeting, the seismologist was trying to get a reluctant slide projector to work and found himself squatted down with one hand extended to adjust the projector and the other extended in the opposite direction to wiggle the electric plug. At this point, some wit in the audience piped up: "Now whistle Dixie." A third story concerned an earthquake engineering colleague who was markedly overweight and an accident he had in Japan. The incident occurred when the colleague visited a Japanese professor who lived in a traditional home. Apparently, the colleague entered the doorway, removed his shoes, walked into the room, and promptly broke through the floor.

In 1989 I became provost and moved my office from Thomas Laboratory to Caltech's administration building. As a result of this move and my new duties, I saw much less of George and my other earthquake engineering colleagues than I had before. George and I did meet occasionally at faculty seminars and at social occasions, but I no longer had the close contact we had when we worked together on projects. His closest colleague over the last two decades of his life was Professor John Hall. John worked with George on technical projects, but he and his wife, Nancy, also helped George move from his house to the retirement apartment at Villa Gardens and assisted George in disposing of his enormous collections of books and music. In George's final years, Nancy also managed his finances and helped him in many ways as he dealt with his declining capabilities.

I talked with George many times by phone these past few years. In the last year or so, it seemed clear to me that he preferred this to a visit. Although his physical strength was fading, 
in my last call just two weeks before his death he was still very sharp mentally and continued to show his remarkable memory. George had a profound influence on my life and was certainly one of the two or three most able people I have ever known. The profession of earthquake engineering is very fortunate to have such a gifted man as a pioneer in the field. $\mathbf{z}$

Paul C.Jennings Professor of Civil Engineering and Applied Mechanics, Emeritus California Institute of Technology pcjenn@caltech.edu
Note from the Editor:

Susan Newman, Executive Director of SSA, notes that "George was a very gentle and perceptive man who got many things done well, generally in a patient and quiet way."

George $W$. Housner joined the Seismological Society of America in 1943, making him one of its longest serving members. He was the Society's President from 1977 to 1978, and in 1981 be received the Harry Fielding Reid Medal, the highest honor of the Society, when he became an honorary member. 